\title{
要支援・軽度要介護高齢者における 抑うつとサルコペニアの関係
}

\author{
Relationship between Depression and Sarcopenia in Japanese Elderly \\ with Mild Long-term Care or Support Needs
}

$\begin{array}{llllll}\text { 佐藤 } & \text { 稜 }^{1)} & \text { 沢谷 } & \text { 洋平 }^{2)} & \text { 柴 }^{\text {隆広 }}{ }^{3)} & \text { 広瀬 } \\ \text { 環 }\end{array}$

RYo SATO, RPT ${ }^{1)}$, YoHeI SAWAYA, RPT, MS ${ }^{2)}$, TAKAHIRo SHIBA, RPT ${ }^{3)}$, TAMAKI HIROSE, RPT ${ }^{2)}$, MinAmi SATO, RPT ${ }^{1)}$, MASAHIRo ISHIZAKA, RPT, $\mathrm{PhD}^{2)}$, AKIRA KUBO, RPT, PhD ${ }^{2)}$

${ }^{1)}$ Division of Physical Therapy, Master Program in Health Sciences, Graduate School of Health and Welfare Sciences, International University of Health and Welfare: 2600-1 Kitakanemaru, Ohtawara-shi, Tochigi 324-8501, Japan TEL+81287-24-3018E-mail:19s1095@g.iuhw.ac.jp

2) Department of Physical Therapy, School of Health Science, International University of Health and Welfare

3) Department of Day Rehabilitation, Care Facility for the Elderly "Maronie-en"

Rigakuryoho Kagaku 35(5): 673-677, 2020. Submitted Apr. 13, 2020. Accepted May 28, 2020.

ABSTRACT: [Purpose] To clarify the relationship between depression and sarcopenia in Japanese elderly receiving day-care through the long-term care insurance system. [Participants and Methods] Seventy-nine community-dwelling individuals (45 males and 34 females) aged more than 65 years, who required support level 1, level 2, or care level 1 support and were receiving day-care through the long-term care insurance system were enrolled. We examined the relationship between the prevalence of sarcopenia and the degree of depression, muscle strength, physical function, and skeletal muscle mass index. [Results] A significant association between the degree of depression and the prevalence of sarcopenia was only observed in males. In addition, a significant decrease in skeletal muscle mass index was observed in males as their depression worsened. No significant difference was observed in females. [Conclusion] This study found that there is a gender difference in the relationship between depression and sarcopenia. A relationship between depression and sarcopenia was found among elderly males who received day care through the long-term care insurance system.

Key words: depression, sarcopenia, requiring long-term care

要旨：〔目的〕要支援・軽度要介護高齢者に拀ける抑うつとサルコペニアの関係を明らかにすること.〔対象と方法〕 通所リハビリテーション利用者, 要支援 1 ・要支援 $2 \cdot$ 要介護 1 の 65 歳以上の高齢者 79 名, 男性 45 名, 女性 34 名 を対象とした，抑うつの程度におけるサルコペニアの有病率と抑うつの程度における筋力，身体機能，骨格筋量の関 係を検討した。〔結果〕男性のみ抑うつの程度とサルコペニアの有病率に有意な関連を認めた。また，男性は抑うつ が強くなるに伴い骨格筋量の有意な低下が認められた。女性においては有意差が認められなかった。〔結語〕抑うつ とサルコペニア間に, 性差が存在し男性要支援・軽度要介護高齢者において抑うつとサルコペニアに関連があること が明らかとなった

キ一ワード : 抑うつ, サルコペニア, 要支援・軽度要介護高齢者

\footnotetext{
1) 国際医療福祉大学大学院修士課程 医療福祉学研究科 保健医療学専攻 理学療法学分野：栃木県大田原市北金丸 2600-1 ( ₹ 324-8501) TEL 0287-24-3018

2) 国際医療福祉大学 保健医療学部 理学療法学科

3) 介護老人保健施設マロニエ苑 通所リハビリテーション

受付日 2020 年 4 月 13 日 受理日 2020 年 5 月 28 日
} 


\section{I.はじめに}

我が国の高齢者が要支援・および要介護 1 に至る原因 の第 2 位は加齢による衰弱であり，加齢による衰弱は軽 度要介護高齢者の占める割合が高いとされている ${ }^{1)}$ 。 そ して, 加齢に伴って生じる骨格筋量と骨格筋力の低下を サルコペニアといい, サルコペニアになると転倒のリス クが高くなる2)ため要介護状態になる恐れがある。高 齢者におけるサルコペニアの要因は加齢以外に原因がな い加齢性サルコペニア（1 次性サルコペニア），身体活 動性サルコペニア・疾患性サルコペニア・栄養性サルコ ペニア（2 次性サルコペニア）など多岐にわたる3)。また サルコペニアは抑うつとの関連が多数報告されてい る ${ }^{4-7)}$.

抑うつには抑うつ気分, 抑うつ症状, 臨床的な精神疾 患としてのうつ病が含まれる。抑うつ気分とは, 日常生 活で誰もが経験する, 悲しくなった, 憂うつになった, ふさぎ込んだ，落ち込んだ気分のことである，抑うつ症 状とは, 抑うつ気分と趣味・喜びの免失に加え, 体重・ 食欲の著しい変化, 睡眠の変化, 精神活動性の障害, 易 疲労性, 罪責感, 集中困難および自殺念虚や自殺企図と いった複数の心身の状態から定義される ${ }^{8)}$. 抑うつは, 病気や障害の有病率を高め, 生活の質の低下, 死亡率に 関連していると報告されている9)。本邦では, 財政負担 軽減のためうつ予防関連事業の促進が極めて重要な課題 となっている，厚生労働省はうつ状態が強くなると, 身 体の健康状態にも影響することから, 高齢者のうつ対策 は生活習慣病予防・進展防止, ひいては要支援・要介護 高齢者を少なくするためにも重要であると報告してお り 10), うつ症状の早期発見によって, 病気の進行や障 害への移行を予防することの重要性を指摘している。 そ して, 抑うつ11) とサルコペニア 12) は健常高齢者に比べ 要支援・要介護高齢者で有病率が高いことが報告されて いる。

しかしながら, 抑うつとサルコペニアの関係性は Asian Working Group for Sarcopenia（AWGS）の診断基 準の項目である歩行速度, 握力, 骨格筋量を同時に測定 している研究が少なく, また海外の健常地域在住高齢者 を対象とした研究であり, 要支援・軽度要介護高齢者に おいて抑うつとサルコペニアの関連が明らかにされてい ない.これらのことより抑うつの程度におけるサルコペ ニアの有病率をアウトカムとしてサルコペニアの項目で ある筋力・身体機能・骨格筋量も含めて検証することは, 本邦における介護予防での高齢社会の現状分析の確立に つながるための一助になりえると考える。

以上のことより本研究では，要支援・軽度要介護高齢 者の抑うつの程度とサルコペニアの有病率に関連がある と仮説を立案し, その後サルコペニアの項目である筋力, 身体機能, 骨格筋量と比較することで抑うつとサルコペ
ニアの関係性の特徵について検証することを目的とした。

\section{II. 対象と方法}

1. 対象

対象は栃木県北部の通所リハビリテーション事業所の 利用者で要支援 $1 \cdot 2$ および要介護 1 の認定を受けてい る 79 名, 男性 45 名, 女性 34 名, 年齢 $78.6 \pm 6.9$ 歳 (平 均 \pm 標準偏差）である。除外基準は，1）検査に対す る指示理解が困難な者，2）認知症と診断された者，3） 65 歳未満の者とした。実施にあたり全対象者に目的お よび測定に関する説明を十分に行い, 参加の同意を得 た。本研究は国際医療福祉大学倫理審査委員会の承認を 得て行った（承認番号：17-Io-189-6）.

\section{2. 方法}

評価項目は歩行速度, 握力, 体組成分, 老年期うつ病 評価尺度（Geriatric depression scale 15：以下, GDS15）とし, サルコペニア診断は Asian Working Group for Sarcopenia 2019 （以下, AWGS2019）13）の診断基準 に従い, 下記の通りに実施した。

握力は, 握力計 (デジタル握力計グリップ D-TTK54041, 竹井機器工業社製) を使用し, 椅子座位 で左右 2 回ずつ測定したうちの最大值を代表值とした。 歩行速度は $3 \mathrm{~m}$ と $8 \mathrm{~m}$ の地点に印をつけた $11 \mathrm{~m}$ の歩行 路の上を直進歩行し, $3 \mathrm{~m}$ と $8 \mathrm{~m}$ の間 $(5 \mathrm{~m})$ の最大の 歩行速度から算出した。歩行補助具は普段の歩行に使用 している補助具とした。骨格筋量の指標は体組成分析装 置（InBody520，バイオスペース社製）を用いた生体電 気インピーダンス法（以下, BIA 法）で測定し, 四肢 筋肉量を身長の 2 乗で除した Baumgartner らの骨格筋指 数 ${ }^{14)}$ (Skeletal Muscle Mass Index : 以下, SMI) を算出 した。測定肢位は機器の指示に従い立位姿勢とした。 た，身体組成の測定に先立って，久保らの方法 15$)$ を参考 に身長を算出した。身体機能および身体組成の測定は 1 週間の期間を設け，その週の最初の利用日に測定した。

サルコペニア診断はAWGS2019の診断基準に従い, 男性は握力 $28 \mathrm{~kg}$ 未満 (低筋力) - 歩行速度 $1 \mathrm{~m} / \mathrm{s}$ 未満 (低身体機能) - SMI $7.0 \mathrm{~kg} / \mathrm{m}^{2}$ 未満（低骨格筋量），女性 では握力 $18 \mathrm{~kg}$ 末満 (低筋力) ・歩行速度 $1 \mathrm{~m} / \mathrm{s}$ 末満（低 身体機能）・SMI $5.7 \mathrm{~kg} / \mathrm{m}^{2}$ 未満（低骨格筋量）を算出し た. その後, 低骨格筋量 + 低筋力もしくは低身体機能 でサルコペニア，低骨格筋量 + 低筋力 + 低身体機能で 重度サルコペニアと定義し, 本研究ではサルコペニアの 有 (サルコペニア, 重症サルコペニア) ・無（非サルコ ペニア）に分類した.

抑うつの評価は信頼性, 妥当性が確認されている GDS-15を用いた，質問方法は検者間で統一するため, 紙面に印刷された質問項目を読み上げ，対象者に「は 
い」，「いいえ」で回答させた，GDS-15により 5 点未満 が抑うつなし（以下，抑うつなし群）， 5 点以上が抑う つ傾向 (以下, 抑うつ傾向群), 10 点以上が抑うつ状態 (以下, 抑うつ状態群) と診断し， 3 群に分類した.

統計解析は抑うつの程度の 3 群比較のためサルコペニ アの有病率・介護区分において $\chi^{2}$ 検定を実施し, 年齢 · 身長・体重·Body Mass Index (BMI) - 握力 · 歩行速 度·SMI は一元配置分散分析と多重比較検定の Bonferroni 法を用いた。なお，解析ソフトはIBM SPSS Statistics Ver.25 を用い, 有意水準はすべて 5\%とした.

\section{III. 結 果}

表 1 に, 全体 79 名, 男性 45 名, 女性 34 名の基本属 性および測定結果を示す。基本属性および測定結果に関 し, 身長・体重・握力・SMI ・ サルコペニア有病率にお いて男女間に有意差を認めた。

表 2 に抑うつの程度 3 群間の基本属性および測定結果 を示す。抑うつの割合は男性が抑うつなし群 15 名, 抑 うつ傾向群 21 名, 抑うつ状態群 9 名, 女性は抑うつな し群 14 名, 抑うつ傾向群 15 名, 抑うつ状態群 5 名であっ た。男性では, 抑うつの程度の群間でサルコペニア有病 率・SMIに有意差を認めた。

\section{IV. 考 察}

Wada ら 16) は，健常高齢者における「うつ」の割合 はGDS-15で6点以上を「うつ」とした場合, 33\%であっ たと報告している。そして, 葛谷ら11) は介護認定を受
けた在宅療養中の高齢者の「うつ」の割合は, GDS-15 で 6 点以上を「うつ」とした場合, $57.2 \%$ でありその出 現頻度は介護度の上昇に伴い増加したと報告している。 本研究の結果は, 蓦谷らの結果同様に抑うつ傾向以上の 割合が全体の $63.3 \%$ であり, 健常高齢者に比べ要支援・ 軽度要介護高齢者において抑うつの有病率が高いことが 明らかとなった。

抑うつ傾向以上の割合が男性 $66.7 \%$, 女性 58.8\%で あり，「うつ」の割合が男性で高い結果となった。これは, 本研究の対象者の男女間の基本属性の比較において, 男 性のサルコペニア有病率が女性と比較して高いためと考 える. 先行研究より, 握力の低下はうつ病症状のリスク が高いとの報告 6)や, サルコペニアを有している者は, 有していない者と比較して抑うつが高いことが報告 7) されている。したがって，サルコペニアの有病率が男性 で高かったことが，女性と比較して男性において抑うつ が多くなったと考えられる。

抑うつの程度における比較は, 男性のみ抑うつが悪化 するに伴いサルコペニアの有病率が上がり, SMIの低 下が認められた。 60 歳以上の 836 名（男性 378 名, 女 性 458 名）を対象にした報告では，うつ病の高齢男性 はうつ病のない男性よりも四肢骨格筋量が低く, 特に男 性においてうつ病はサルコペニアに関連していたと報告 さている5). 本研究は, 先行研究を支持する結果となっ た。要介護高齢者において抑うつは低栄養との間に関連 を認めており11), そして地域在住要支援・要介護高齢 者において, サルコペニアの主要因は栄養状態と報告さ れている 17). よって, 抑うつとサルコペニアは栄養状 態と間接的に関連していることが考えられる。抑うつの

表 1 対象者の基本属性と測定結果

\begin{tabular}{|c|c|c|c|}
\hline & 全体 & 男性 & 女性 \\
\hline 人数（名） & 79 & 45 & 34 \\
\hline 年齢（歳） & $78.6 \pm 6.9$ & $78.7 \pm 6.7$ & $78.6 \pm 7.2$ \\
\hline 身長（cm） & $159.0 \pm 7.9$ & $164.0 \pm 5.4$ & $152.3 \pm 5.5^{*}$ \\
\hline 体重（kg） & $56.1 \pm 9.9$ & $58.7 \pm 8.5$ & $52.6 \pm 10.8^{*}$ \\
\hline BMI $\left(\mathrm{kg} / \mathrm{m}^{2}\right)$ & $22.2 \pm 3.5$ & $21.8 \pm 2.7$ & $22.7 \pm 4.3$ \\
\hline 握力 $(\mathrm{kg})$ & $21.7 \pm 7.2$ & $25.0 \pm 6.4$ & $17.2 \pm 5.5^{*}$ \\
\hline 歩行速度（m/s） & $0.7 \pm 0.3$ & $0.8 \pm 0.3$ & $0.7 \pm 0.3$ \\
\hline SMI $\left(\mathrm{kg} / \mathrm{m}^{2}\right)$ & $6.5 \pm 1.1$ & $6.7 \pm 1.2$ & $6.1 \pm 1.0^{*}$ \\
\hline サルコペニア有病率（\%) & 48.1 & 62.2 & $29.4^{\dagger}$ \\
\hline GDS-15 5 点未満（\%） & 36.7 & 33.3 & 41.2 \\
\hline 5～9 点（\%） & 45.6 & 46.7 & 44.1 \\
\hline 10 点以上（\%） & 17.7 & 20.0 & 14.7 \\
\hline 介護区分＼cjkstart要支援 1（\%） & 34.2 & 28.9 & 41.2 \\
\hline 要支援 2（\%） & 16.5 & 20.0 & 11.8 \\
\hline 要介護 1（\%) & 49.4 & 51.1 & 47.1 \\
\hline
\end{tabular}

平均值 \pm 標準偏差. BMI : Body Mass Index, SMI : Skeletal Muscle Mass Index, GDS15 ：老年期うつ病評価尺度. $*$ : 対応のない $\mathrm{t}$ 検定 $\mathrm{p}<0.05, \dagger: \chi^{2}$ 検定 $\mathrm{p}<0.05$. 
表 2 抑うつの程度 3 群間の基本属性および測定結果の比較

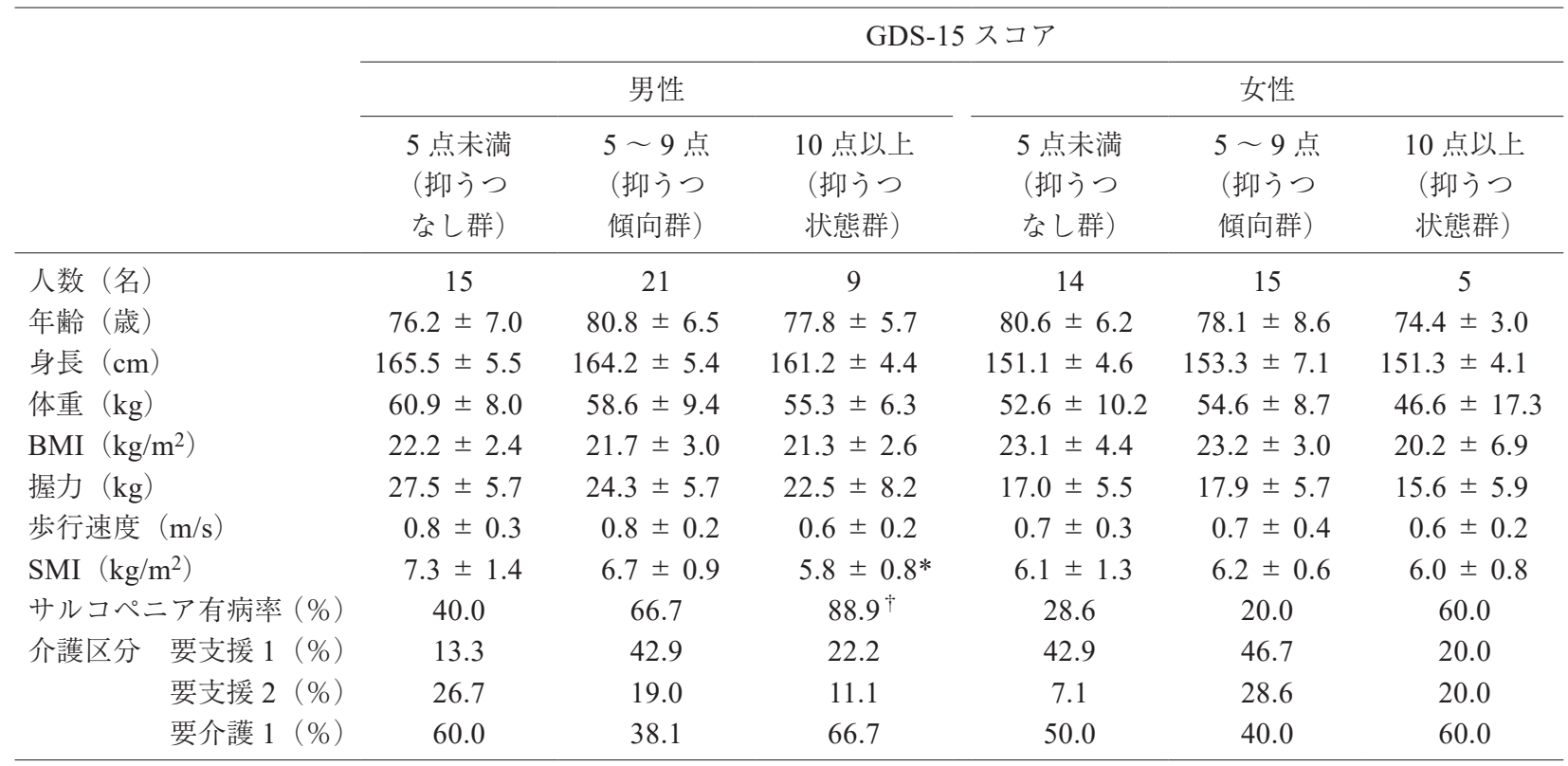

平均值 \pm 標準偏差. GDS-15: 老年期うつ病評価尺度, BMI : Body Mass Index, SMI : Skeletal Muscle Mass Index. $*: \mathrm{p}<0.05$ (Bonferroni) $, \dagger: \mathrm{p}<0.05$ ( $\chi^{2}$ 検定).

男女差について角田ら ${ }^{18)}$ は, 男性のみ余暇活動量にお いてGDS の全ての因子得点と負の関連が認められてい ると報告して抢り，Walsh ら ${ }^{199}$ は，女性高齢者を対象 とした研究で, 中強度以上の余㗇活動と抑うつは関連し ないと報告している。したがって，余㗇活動量と抑うつ 度との負の関連性は特に男性に扔いてみられる。また, 70 歳以上の高齢者 2925 人を対象にした地域高齢者に㧈 けるうつ状態の程度と, その後の介護保険の要介護認定 リスクとのコホート研究では, 男性のみうつ状態と要支 援・要介護認定リスクが関連していると報告してい る ${ }^{20)}$ 。このことから, 男性の抑うつは，身体的な影響 を受けやすい可能性が示唆されている.

本研究上り男性の要支援・軽度要介護高齢者に扔いて 抑うつの程度とサルコペニアの有病率に関係がみられ た。このことから、リハビリテーションに拍ける抑うつ の評価・介入が要介護高齢者の介護予防に貢献できる可 能性があることが示唆された。しかし, 研究の限界とし て抑うつとサルコペニアの 2 要因の関連までしか明らか にできないため, 抑うつと栄養摂取状態, 身体活動量と の関係性を考慮できていない。また，一般的に抑うつは， 男性に比べ，女性で多いとされている 21,22)。60歳以上 の地域高齢者を対象にした報告では, 抑うつの男女の関 連要因に扔いて, 男性は「年収」,「主観的健康度」, $\lceil\mathrm{ADL} 」, 「$ 居住形態」の 4 要因に抑うつとの関連が認め られ, 女性では「子供の数」,「主観的健康度」,「受医療 頻度」,「ADL」,「居住形態」の 5 要因と抑うつとの関 連が認められて抢り, 男女に执いて抑うつの要因が違う
ことが報告されている ${ }^{21)}$ ，そして，ADL の低下はサル コペニアと関連が報告されている3)。本研究のサンプル に扔いて, 男女間のサルコペニア有病率に有意差があっ たことが，女性に扔いて抑うつとサルコペニアに有意差 を認めなかった可能性も考えられる。本研究では抑うつ がサルコペニアの有病率と関連することが示唆されたが, 横断的な分析であり因果関係は不明である。今後は栄養 指標, 活動指標を含めて, 抑うつとサルコペニアの関係 性を再検討し, 対象者を縦断的に追跡し抑うつとサルコ ペニアの因果関係を検討していくことが求められる.

利益相反 本論文に関して開示すべき利益相反はない.

謝辞 本研究を実施するうえで調査にご協力頂いた，に しなすの総合在宅ケアセンターの利用者と職員の皆様に 感謝致します。

\section{引用文献}

1) 厚生労働省: 国民生活基礎調査（平成 28 年調查結果). https://www.mhlw.go.jp/toukei/list/d1/20-21-h28_rev2.pdf（閲 覧日2020年4月 4 日).

2) Landi F, Liperoti R, Russo A, et al.: Sarcopenia as a risk factor for falls in elderly individuals: results from the ilSIRENTE study. Clin Nutr, 2012, 31: 652-658.

3) サルコペニア診療ガイドライン作成委員会 : サルコペニア 診療ガイドライン 2017 年版. https://minds.jcqhc.or.jp/docs/ g1_pdf/G0001021/4/sarcopenia2017.pdf（閲覧日2020年4月 
4 日)

4) Chang KV, Hsu TH, Wu WT, et al.: Is sarcopenia associated with depression? A systematic review and meta-analysis of observational studies. Age Ageing, 2017, 46: 738-746.

5) Kim NH, Kim HS, Eun CR, et al.: Depression is associated with sarcopenia, not central obesity, in elderly Korean men. J Am Geriatr Soc, 2011, 59: 2062-2068.

6) Hsu YH, Liang CK, Chou MY, et al.: Association of cognitive impairment, depressive symptoms and sarcopenia among healthy older men in the veterans retirement community in southern Taiwan: a cross-sectional study. Geriatr Gerontol Int, 2014, 14: 102-108.

7) Hamer M, Batty GD, Kivimaki M: Sarcopenic obesity and risk of new onset depressive symptoms in older adults: English Longitudinal Study of Ageing. Int J Obes, 2015, 39: 17171720.

8) 石川信一, 岩永三智子, 山下文大・他：社会的スキル訓練 による児童の抑うつ症状への長期的効果. 教育心理学研究, 2010, 58: 372-384.

9) Charney DS, Reynolds CF 3rd, Lewis L, et al. Depression and Bipolar Support Alliance: Depression and Bipolar Support Alliance consensus statement on the unmet needs in diagnosis and treatment of mood disorders in late life. Arch Gen Psychiatry, 2003, 60: 664-672.

10) 厚生労働省：介護予防マニュアル（改正版平成 24 年 3 月）. https://www.mhlw.go.jp/topics/2009/05/dl/tp0501-1_09.pdf (閲覧日 2020 年 4 月 4 日).

11) 葛谷雅文, 益田雄一郎, 平川仁尚·他：在宅要介護高齢者 の「うつ」発症頻度ならびにその関連因子. 日本老年医学会 雑誌, 2006, 43: 512-517.

12) 沢谷洋平, 石坂正大, 久保 晃・他: 通所リハビリテーショ
ン利用者におけるサルコペニアの有病率とその特徵. 理学 療法科学, 2019, 34: 111-114.

13) Chen LK, Woo J, Assantachai P, et al.: Asian Working Group for Sarcopenia: 2019 Consensus update on sarcopenia diagnosis and treatment. J Am Med Dir Assoc, 2020, 21: 300307.e2.

14) Baumgartner RN, Koehler KM, Gallagher D, et al.: Epidemiology of sarcopenia among the elderly in New Mexico. Am J Epidemiol, 1998, 147: 755-763.

15) 久保 晃, 啓利英樹：前腕長と下腿長を用いた高齢者の身 体推定. 理学療法科学, 2007, 22: 115-118.

16) Wada T, Ishine M, Sakagami T, et al.: Depression in Japanese community-dwelling elderly_prevalence and association with ADL and QOL. Arch Gerontol Geriatr, 2004, 39: 15-23.

17) 加茂智彦, 鈴木留美子, 伊藤 梢 - 他 : 地域在住要支援 · 要介護高齢者におけるサルコペニアに関する要因の検討. 理学療法学, 2013, 40: 414-420.

18) 角田健二, 大藏倫博: 高齢者の身体活動量と心理的状態, ソー シャルネットワークとの関連性. Jpn J Test Eval Phys Educ Sports, 2011, 11: 1-11.

19) Walsh JM, Pressman AR, Cauley JA, et al.: Predictors of physical activity in community-dwelling elderly white women. J Gen Intern Med, 2001, 16: 721-727.

20) 大森 芳, 寶澤 篤, 曽根稔雅・他：うつ状態と介護保険 要支援・要介護認定リスクとの関連 鶴ヶ谷プロジェクト. 日本公衆衛生雑誌, 2010, 57: 538-549.

21) 出村慎一, 多田信彦, 松沢甚三郎：地方都市在住在宅高齢 者における抑うつと生活要因の関係年代及び性別比較. 教 育医学, 2003, 48: 322-330.

22) 青木邦男：高齢者の抑うつ実態と関連要因. 老年精神医学 雑誌, 1997, 8: 401-410. 